\title{
What Do Workers Want From (Private) Government? Experimental Evidence from the United States $^{*}$
}

\author{
Soumyajit Mazumder ${ }^{\dagger}$ Alan Yan ${ }^{\ddagger}$
}

Date last updated: April 28, 2020

\begin{abstract}
Much of the American labor force spends time in "private governments" over which they have little say during and beyond the work day. Do Americans prefer to work for businesses that look more like democracies or autocracies? We study this question using conjoint experimental techniques on a large sample of Americans. This design allows us to vary a large number of features of the workplace-especially their governance structures and the degree to which these structures allow for meaningful democratic decision-making. We hypothesize that workers should have a preference for democratic corporate governance structures such as employee ownership, codetermination, and the direct election of management especially so after experimentally manipulating class identity. The results of this project will contribute to literatures across management, economic sociology, and political science by empirically investigating the problem of the "corporate regime type" from the bottom-up.
\end{abstract}

\footnotetext{
*We would like to thank Alex Hertel-Fernandez for helpful comments and discussions on early stages of the project. We would like to thank the Harvard Digital Laboratory for Social Sciences for fielding a pilot study. Soumyajit Mazumder acknowledges support by the James M. and Cathleen D. Stone Ph.D. Scholar Fellowship from the Multidisciplinary Program in Inequality \& Social Policy at Harvard University. This work has been approved by the Harvard Institutional Review Board (IRB19-1289) and Princeton Institutional Review Board (IRB 12814).

${ }^{\dagger}$ Department of Government, Harvard University

${ }^{\ddagger}$ Department of Politics, Princeton University
} 


\section{INTRODUCTION}

Markets, at their best, ostensibly should reflect a deeply democratic space where consumers and producers can express their preferences through exit, voice, or loyalty (Hirschman 1972). But even if we accept such an ideal, the nature of production through the modern firm exposes a democratic dilemma hinted at by economists such as Coase (1937, pg. 387): production within the modern firm is organized via dictatorial control. As philosopher Elizabeth Anderson notes, "There are no internal markets in the modern workplace. Indeed, the boundary of the firm is defined as the point at which markets end and authoritarian centralized planning and direction begin" (Anderson 2017, pp. 37-39). Ironically, the non-market way in which production is organized within the firm makes it look more like a "communist dictatorship" than a democracy. This elucidates the core research question we seek to understand: do businesses tend to have little resemblance to democracies because workers simply prefer not to work at firms that may ask of them to be democratic citizens on-the-clock?

We study this question by surveying a large sample of Americans and ask them a broad range of questions related to inequality in the workplace. Most importantly, we embed a unique, conjoint experimental task asking respondents to choose the types of firms they would prefer to work at. Our experimental design, commonly used in the marketing literature and increasingly in political science, has the advantage of randomly varying a large array of attributes of these hypothetical firms. Particularly to study preferences toward democratic corporate governance institutions, we randomly vary the presence of various policies such as employee ownership, co-determination, and the direct election of management by employees. In addition to ascertaining the marginal effect of such policies on labor supply at the extensive margin, we also ask respondents a series of questions probing why they prefer various types of working conditions and how they evaluate trade-offs. By using a conjoint experimental design, we are also able to benchmark estimated effects against standard contract terms such as benefit policies, expected hours of work, and salary.

This project contributes to and extends several streams of literature in the political economy of the workplace. Broadly, our project extends existing work in economics and management that focus on preferences for types of work along economic dimensions such as compensation, flexibility, and benefits (Kostiuk 1990; Freeman and Rogers 2006; Eriksson and Kristensen 2014; Flory, Leibbrandt, and List 2015; Mas and Pallais 2017; Beglo and Gorges 2018; Wiswall and Zafar 2018). Building on work by Freeman and Rogers (2006) and Kochan et al. (2019), we argue that workers not only have preferences over the economic fundamentals of 
labor arrangements, but also the political fundamentals over the supply of labor (Dahl 1986; Gourevitch 2014; Anderson 2017). This implies that studies of labor supply and job search overlook an important dimension of work. By using a conjoint experimental design, we are able to elicit preferences over the political arrangements of work and compare them to preferences over economic arrangements holding all else equal. While our study most closely relates to recent work by Hertel-Fernandez, Kimball, and Kochan (2019) who focus on preferences over union arrangements and collective bargaining, we complement this work by highlighting how alternative governance arrangements shape the types of firms Americans want to work at.

\section{HYPOTHESES}

We hypothesize the following main effects with respect to the structure of preferences:

1. Workers will prefer being shareholders and electing their managers relative to having their firm privately owned by an owner or outside shareholders.

2. Workers will prefer larger firms to small firms.

3. Workers will prefer sick leave over no sick leave policy.

4. Workers will prefer employer provided health insurance.

5. Workers will prefer fewer hours rather than more hours of work.

6. Workers will prefer to work at firms with a commitment to corporate social responsibility.

7. Workers will prefer to work at firms with generous parental leave policies.

8. Workers will prefer to work at firms with a mix of repetitive and creative tasks.

9. Workers will prefer to work at firms that fully match retirement contributions.

10. Workers will prefer to work at firms located in their city.

11. Workers will prefer to work at unionized firms.

12. Workers will prefer to work at firms characterized by friendly and supportive work environments. 
13. Workers will prefer to work at firms with job training programs for disadvantaged groups.

14. Workers will prefer to work at firms with higher salaries.

We hypothesize the following moderating effects with respect to the structure of preferences:

1. Workers will prefer being shareholders and electing their managers relative to having their firm privately owned by an owner or outside shareholders especially among nonmanagement employees.

2. Workers will prefer being shareholders and electing their managers relative to having their firm privately owned by an owner or outside shareholders especially among union members if workplace democracy is complementary to unionization.

3. Workers will prefer being shareholders and electing their managers relative to having their firm privately owned by an owner or outside shareholders especially among nonunion members if workplace democracy is a substitute to unionization.

4. Workers will prefer being shareholders and electing their managers relative to having their firm privately owned by an owner or outside shareholders especially among those worried about COVID-19's impact on the economy.

5. Workers will prefer being shareholders and electing their managers relative to having their firm privately owned by an owner or outside shareholders especially among those who are committed to liberal democracy as a political system.

6. Workers will prefer being shareholders and electing their managers relative to having their firm privately owned by an owner or outside shareholders especially among those who are more engaged in politics at work.

7. Workers will prefer being shareholders and electing their managers relative to having their firm privately owned by an owner or outside shareholders especially among those who have the most and least workplace voice.

8. Workers will prefer being shareholders and electing their managers relative to having their firm privately owned by an owner or outside shareholders especially among those whose class identity is salient. 
Figure 1: Example of Conjoint Profile

\begin{tabular}{|l|l|l|}
\hline & \multicolumn{1}{|c|}{ Transportation and warehouse Firm 3 } & Transportation and warehouse Firm 4 \\
\hline Hours of Work & 60 hours a week & 60 hours a week \\
\hline Racial Diversity Practices & All people of color owned & Majority people of color owned \\
\hline Type of Task & Largely repetitive work & Largely creative work \\
\hline Gender Diversity Practices & Majority-men owned & Majority-men owned \\
\hline Paid Sick Leave & No paid sick leave & No paid sick leave \\
\hline Parental Leave & No parental leave policy & No parental leave policy \\
\hline Retirement Matching & Matches 25\% of 401k contributions & Matches 75\% of 401k contributions \\
\hline Firm Size & 1,000 co-workers & 1,000 co-workers \\
\hline Health Insurance Contribution & Employers pays 50\% & Employers pays 50\% \\
\hline Work with Others & Mix of individual and team work & Mix of individual and team work \\
\hline Corporate Social Responsibility & Commitment to corporate social responsibility & No corporate social responsibility \\
\hline Corporate Governance Structure & Privately owned by one individual & Workers sit on the corporate board \\
\hline Workplace Conditions & Somewhat friendly and supportive & Generally unfriendly and unsupportive \\
\hline Work From Home & Cannot work from home & Cannot work from home \\
\hline Location & Located in your city & Located in your city \\
\hline Unionization & Unionized & Not unionized \\
\hline Job Training Program & Ex-felons training & Mentally-disabled training \\
\hline Firm's Political Contributions & Donates to both Democrats and Republicans & Donates to both Democrats and Republicans \\
\hline
\end{tabular}

9. Workers will prefer being shareholders and electing their managers relative to having their firm privately owned by an owner or outside shareholders especially among those with little exit ability from the labor market.

\section{EXPERIMENTAL DESIGN}

We use a conjoint survey to attain a comprehensive sense for Americans' preferences toward the workplace. Conjoint surveys are an increasingly popular survey tool in political science (BansakHainmuellerHopkins2018PA; Hainmueller, Hopkins, and Yamamoto 2014; Hainmueller and Hopkins 2014; Bansak et al. 2018), and they have been shown to approximate real-world behavior (Hainmueller, Hangartner, and Yamamoto 2015). Our experiment places respondents in the position of a job seeker weighing different job offers. After introducing respondents to the task, we show respondents two firm profiles as displayed below in Figure 1.

After reading the firm profiles, respondents answer five outcomes measures. The first question forces respondents to indicate at which firm they would rather work. We code the responses to the question as a binary variable, Firm Preferred, which is 1 if the firm is preferred 
and 1 otherwise. This is our key dependent variable. This variable approximates the real labor market in that when someone accepts a job offer, they must reject the other offer. We then use two outcome variables to measure whether respondents believe that more democratic workplaces improve their day-to-day work experiences. We ask respondents which firm is "best at resolving any problems or complaints that arise at work" and at which firm they think "workers would have more power." Both measures are forced choice. Additionally, we ask respondents at which firm they think they would have more responsibilities to see whether workers realize that more democratic workplaces would require them to take on some managerial responsibilities. Finally, we include an open-ended question for respondents to express why they prefer one firm over the other. This question helps us capture any other reasons that we might miss.

Each respondent evaluates four comparisons between pairs of firms, each displayed on a new page. We randomly vary the two firms' profiles of 19 attributes that one would might consider when choosing between job offers. The attributes include each firm's corporate governance, firm size, sick leave policy, health insurance, work hours, race of owners, gender of owners, corporate social responsibility commitment, parental leave policy, characterization of their work, retirement fund, relocation requirements, unionization, working conditions, specialized job training programs, work from home policy, political donations, and income offer. Each of these attributes could take on multiple values. For example, corporate governance, our main variable of interest, can take on the values: "Workers sit on the corporate board," "Workers elect their managers," "Workers are shareholders," "Privately owned by non-worker shareholders," "Publicly owned by shareholders," and "Privately owned by one individual." We randomly assigned the values for each attribute for each profile so that the two firms vary within and across comparisons. We also randomize the order in which attributes are listed to avoid primacy or recency effects. Tables 1 and 2 contains the full list of attribute values.

A conjoint survey can address several weaknesses that observational and other experimental designs face. First, because every attribute value is independently randomized, the design allows us to decouple attribute values that may be highly correlated in reality. For example, we can imagine that worker-friendly corporate governance may be correlated with higher pay, better benefits, and safer working conditions. Second, the design allows us to compare the relative importance of each attribute. For example, we can directly compare respondents' preference for workplace democracy against their preferences for higher income. Finally, we can investigate whether some respondents prefer certain types of workplaces by interacting respondent and firm characteristics. For example, managerial workers may prefer 
Table 1: Conjoint Attributes and Levels

\begin{tabular}{|c|c|}
\hline \multirow[t]{6}{*}{ Attributes } & Values \\
\hline & Workers elect their managers \\
\hline & Workers are shareholders \\
\hline & Privately owned by non-worker shareholders \\
\hline & Publicly owned by shareholders \\
\hline & Privately owned by one individual \\
\hline \multirow[t]{5}{*}{ Firm Size } & 50 co-workers \\
\hline & 250 co-workers \\
\hline & 500 co-workers \\
\hline & 1,000 co-workers \\
\hline & 5,000 co-workers \\
\hline \multirow[t]{3}{*}{ Paid Sick Leave } & No paid sick leave \\
\hline & Two weeks paid sick leave days \\
\hline & Unlimited paid sick leave days \\
\hline \multirow[t]{3}{*}{ Health Insurance Contribution } & Employers pays $50 \%$ \\
\hline & Employers pays $75 \%$ \\
\hline & Employers pays $100 \%$ \\
\hline \multirow[t]{5}{*}{ Hours of Work } & 40 hours a week \\
\hline & 50 hours a week \\
\hline & 60 hours a week \\
\hline & 70 hours a week \\
\hline & 80 hours a week \\
\hline \multirow[t]{4}{*}{ Racial Diversity Practices } & All people of color owned \\
\hline & Majority people of color owned \\
\hline & Majority white owned \\
\hline & All White owned \\
\hline \multirow[t]{4}{*}{ Gender Diversity Practices } & Women owned \\
\hline & Majority-women owned \\
\hline & Majority-men owned \\
\hline & Men owned \\
\hline
\end{tabular}


Table 2: Conjoint Attributes and Levels

Attributes
Corporate Governance
Corporate Social Respon
Parental Leave
Type of Task
Work with Others
Retirement Matching
Location
Unionization
Workplace Conditions

Job Training Program

Work from Home

Firm's Political Contributions

Income

\section{Values}

Workers sit on the corporate board

No corporate social responsibility

Commitment to corporate social responsibility

No parental leave policy

Generous parental leave policy

Largely repetitive work

Mix of repetitive and creative work

Largely creative work

Mostly working alone

Mix of individual and team work

Mostly team work

Matches $100 \%$ of $401 \mathrm{k}$ contributions

Matches $75 \%$ of $401 \mathrm{k}$ contributions

Matches $50 \%$ of $401 \mathrm{k}$ contributions

Matches $25 \%$ of $401 \mathrm{k}$ contributions

Matches $0 \%$ of $401 \mathrm{k}$ contributions

Located in your city

Located in a different city

Located in a different city but pays for relocation

Unionized

Not unionized

Generally friendly and supportive

Somewhat friendly and supportive

Somewhat unfriendly and unsupportive

Generally unfriendly and unsupportive

Veterans training

Mentally-disabled training

Ex-felons training

No special job training program

Primarily work from home

Sometimes work from home

Cannot work from home

Primarily donates to Democrats

Donates to both Democrats and Republicans

Primarily donates to Republicans

$\$ 30,000$ to $\$ 300,000$ in $\$ 10,000$ increments 
more authoritarian workplaces because democratic workplaces challenge their power.

\section{MODERATOR VARIABLES}

Employment: We first ask respondents whether they are employed. If yes, they are asked how they are employed (e.g. full-time, part-time, temporary, contract, independent contractor, or on-call).

Workplace power: We have several questions that measure workplace power. We first ask if the person supervises other workers. After, we ask whether they are an owner, related to an owner, or part of upper-level management. Additionally, we use a set of questions developed by Wright (1997). We ask respondents whether they hold a managerial, supervisory, or nonmanagement job at work. After, if they choose "managerial," then they are asked whether they are a "top," "upper," "middle," or "lower" manager. Then, they are asked if they make decisions about policies at work. We can then use those three questions to create a workplace hierarchy measure.

Union member: We ask respondents whether they are or ever was a member of a union.

Union support: We ask respondents whether they would vote for or against unionization if a union election were held today.

Education: We ask respondents how much education they have completed.

Partisanship: We ask respondents which party they identify with.

Affected by Covid-19: We ask respondents three questions. First, we ask respondents whether they have or anyone they know has tested positive for the virus. Second, we ask respondents whether they have or anyone they know has been laid off. Third, we ask whether respondents are worried about the virus' impact on the economy on a four-point scale.

Liberal democracy: We use four questions to measure whether respondents support liberal democracy taken from the General Social Survey. First, we ask whether respondents believe that it is good or bad having a strong leader who can ignore Congress and elections. Second, we ask whether respondents believe that it is good or bad having experts, not governments, make decisions according to what they think is best. Third, we ask whether respondents believe that it is good or bad having the army rule. Finally, we ask whether respondents believe that it is good or bad having a democratic political system.

Politics at work: We ask respondents whether managers or supervisors encourage them to participate in politics. We then ask whether respondents believe their coworkers are mostly Democrats or Republicans. After, we ask whether respondents believe that their senior man- 
agers and supervisors are mostly Democrats or Republicans. Then, we ask respondents whether coworkers encourage them to participate in politics. Finally, we ask respondents whether they agree or disagree with two statements: people who express political views different from those who run the organization are unlikely to be promoted and people who express political views different from those who run the organization are unlikely to be hired or stay at their job.

Class identification: We ask respondents whether they identify with the lower class, working class, middle class, upper-middle class, or upper class.

Monopsony and Outside Options: We ask respondents to agree or disagree with four statements using a five-point scale. The statements are as follows. First, it would be relatively easy for me to quit my job and find a new one. Second, if I lost my job, it would be easy for me to find a new one. Third, there are enough job opportunities where I live for me to negotiate for better compensation at my current one. Lastly, there are plenty of other employers where I live that likely have jobs open in my occupation.

Workplace voice: We ask respondents a set of questions about how much say they have at work using a five-point scale. The areas we ask about are as follows: (1) your salary and other compensation, (2) your benefit package, (3) your ability to organize your schedule, meaning the times you work, (4) the time you consider necessary to do your job, (5) your ability to choose how you do your job, (6) your access to training opportunities, (7) your opportunities for a promotion, (8) how new technologies affect your job, (9) ways to improve how you and your coworkers do your work, (10) your ability to perform your job safely, (11) your ability to resolve problems or conflicts affect your job, (12) how your employer protects you against discrimination, (13) your job security, (14) how your employer protects you from abuse or harassment, (15) your employer provides its customers, (16) the basic values your employer stands for, and (17) the level of respect shown to you and your coworkers.

\section{POWER ANALYSIS}

Below, we describe a power analysis for each attribute. We set the sample size to 1,000 because that is the highest number of respondents we can get with a DLABSS sample. We set the number of pairs to four and we use 1,000 simulations in our analysis. The shaded blue areas in the histograms below describe what effect we would need to reject the null hypothesis.

Figure 2 shows that we are able to detect an effect approximately as small as 0.054 .

Figure 3 shows that we are able to detect an effect approximately as small as 0.05 .

Figure 4 shows that we are able to detect an effect approximately as small as 0.039 . 


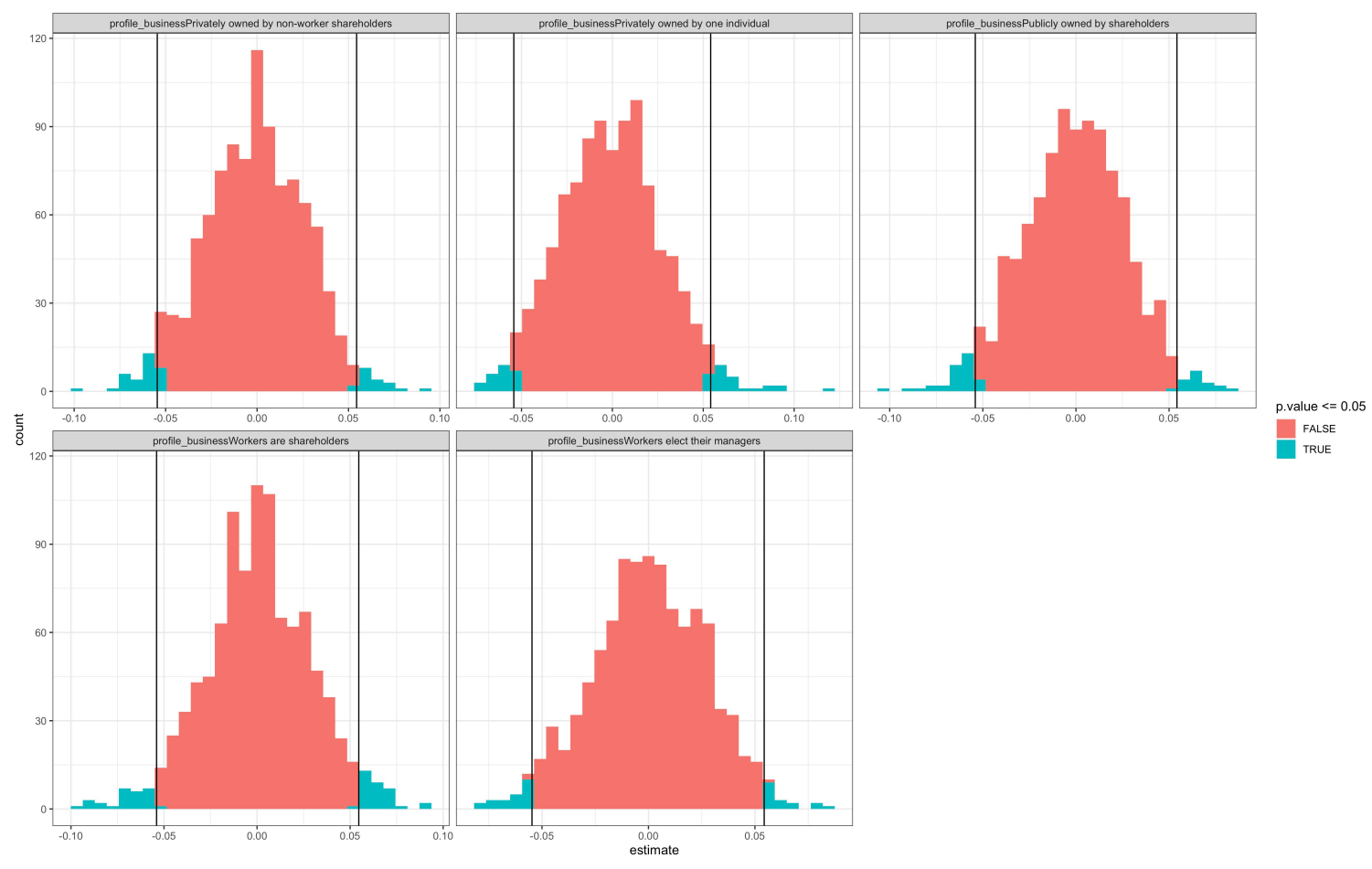

Figure 2: Power analysis of corporate governance attribute levels.

Figure 5 shows that we are able to detect an effect approximately as small as 0.039 . Figure 6 shows that we are able to detect an effect approximately as small as 0.049 . Figure 7 shows that we are able to detect an effect approximately as small as 0.044 . Figure 8 shows that we are able to detect an effect approximately as small as 0.044 . Figure 9 shows that we are able to detect an effect approximately as small as 0.031 . Figure 10 shows that we are able to detect an effect approximately as small as 0.031. Figure 11 shows that we are able to detect an effect approximately as small as 0.039 . Figure 12 shows that we are able to detect an effect approximately as small as 0.039 . Figure 13 shows that we are able to detect an effect approximately as small as 0.049. Figure 14 shows that we are able to detect an effect approximately as small as 0.039 . Figure 15 shows that we are able to detect an effect approximately as small as 0.031 . Figure 16 shows that we are able to detect an effect approximately as small as 0.044 . Figure 17 shows that we are able to detect an effect approximately as small as 0.038. Figure 18 shows that we are able to detect an effect approximately as small as 0.038 . Figure 19 shows that we are able to detect an effect approximately as small as 0.038. 


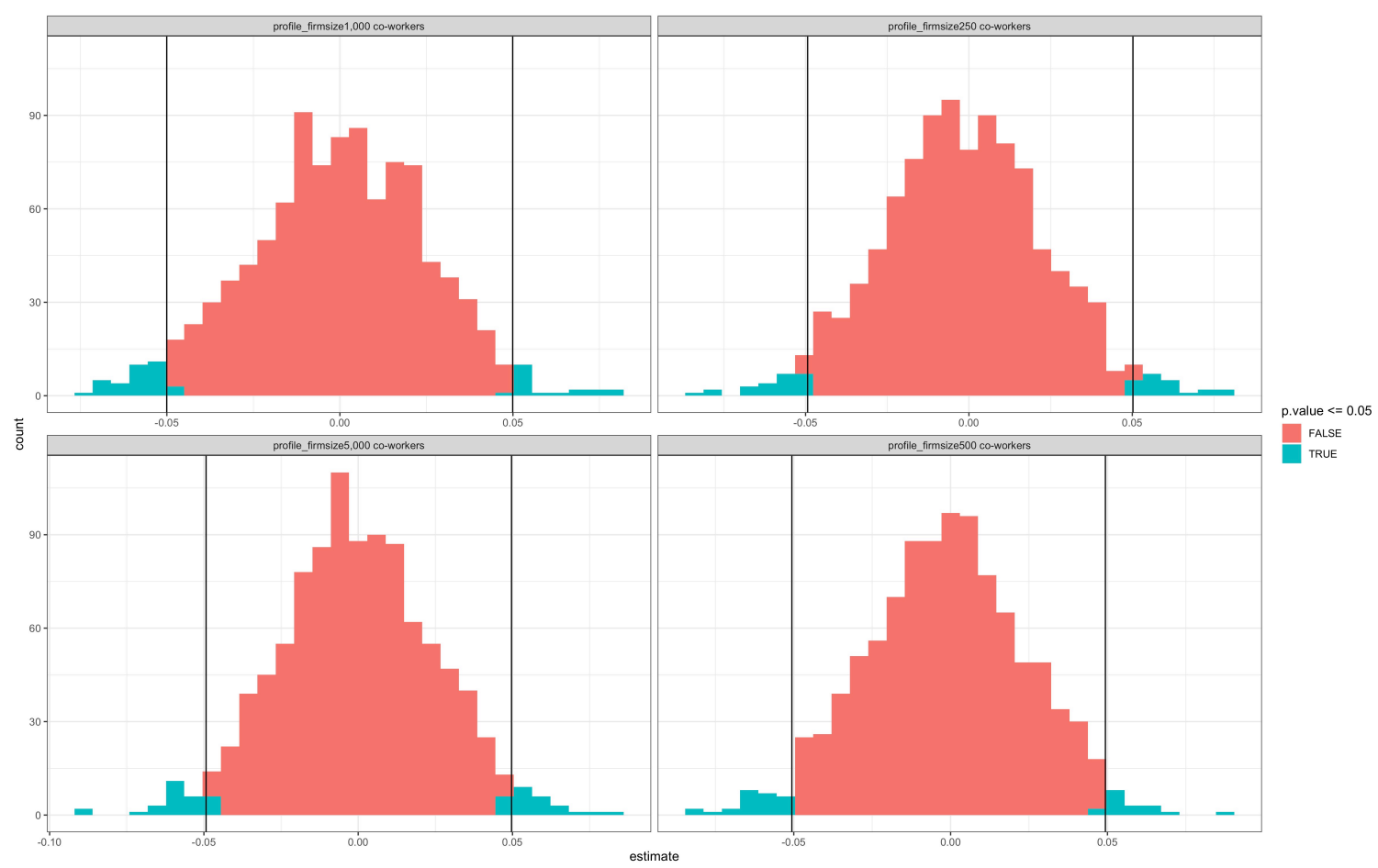

Figure 3: Power analysis of firm size attribute levels.

Figure 20 shows that we are able to detect an effect approximately as small as 0.11 .

\section{SAMPLE}

We will use Harvard's Digital Labs for the Social Sciences (DLABSS) to recruit at most 1,000 respondents. Strange et al. (2019) show that these online volunteer respondents have demographic characteristics comparable to other online panels. Additionally, they reproduce classic and contemporary social science findings and show response quality comparable to paid respondents. 


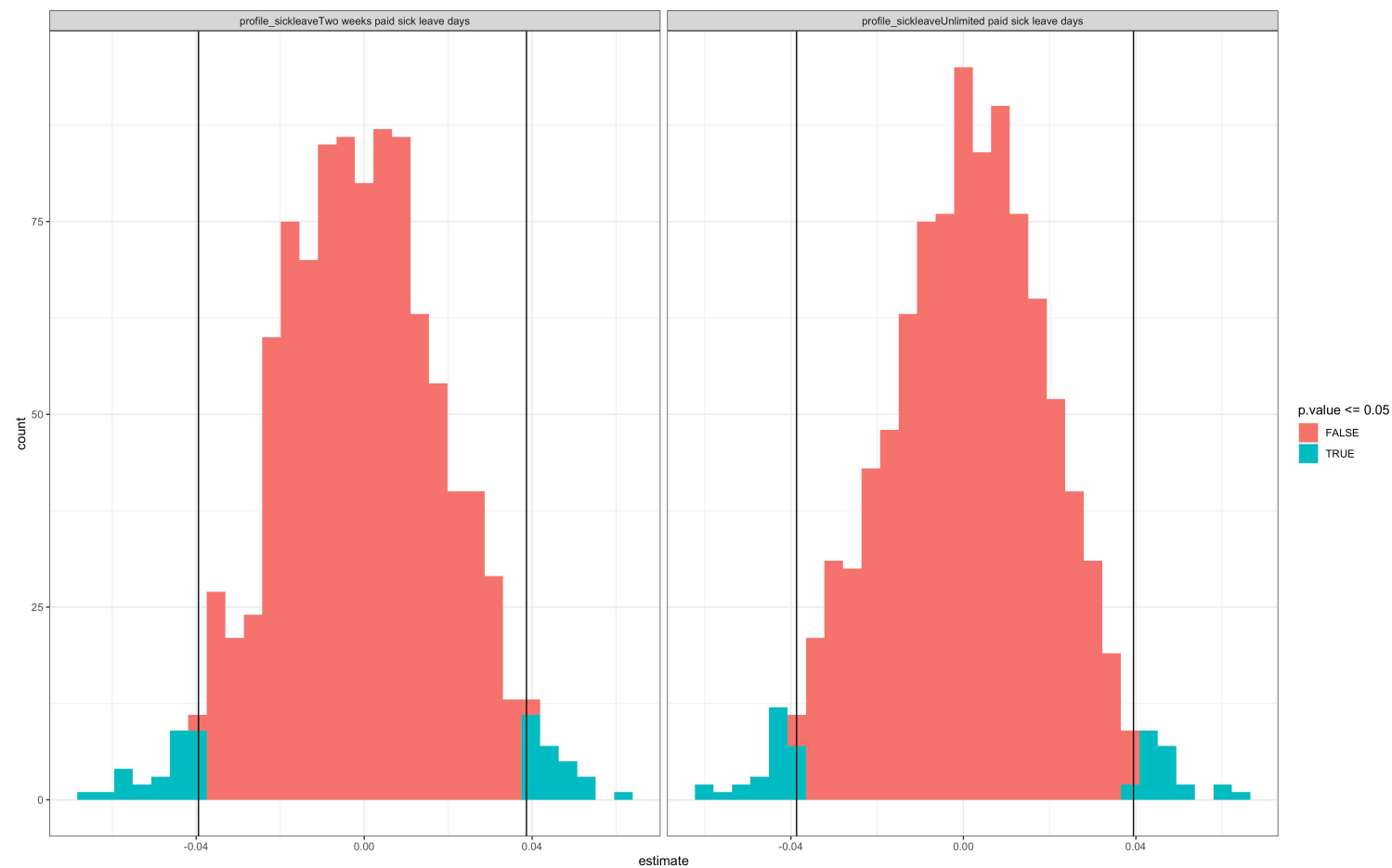

Figure 4: Power analysis of paid sick leave attribute levels. 


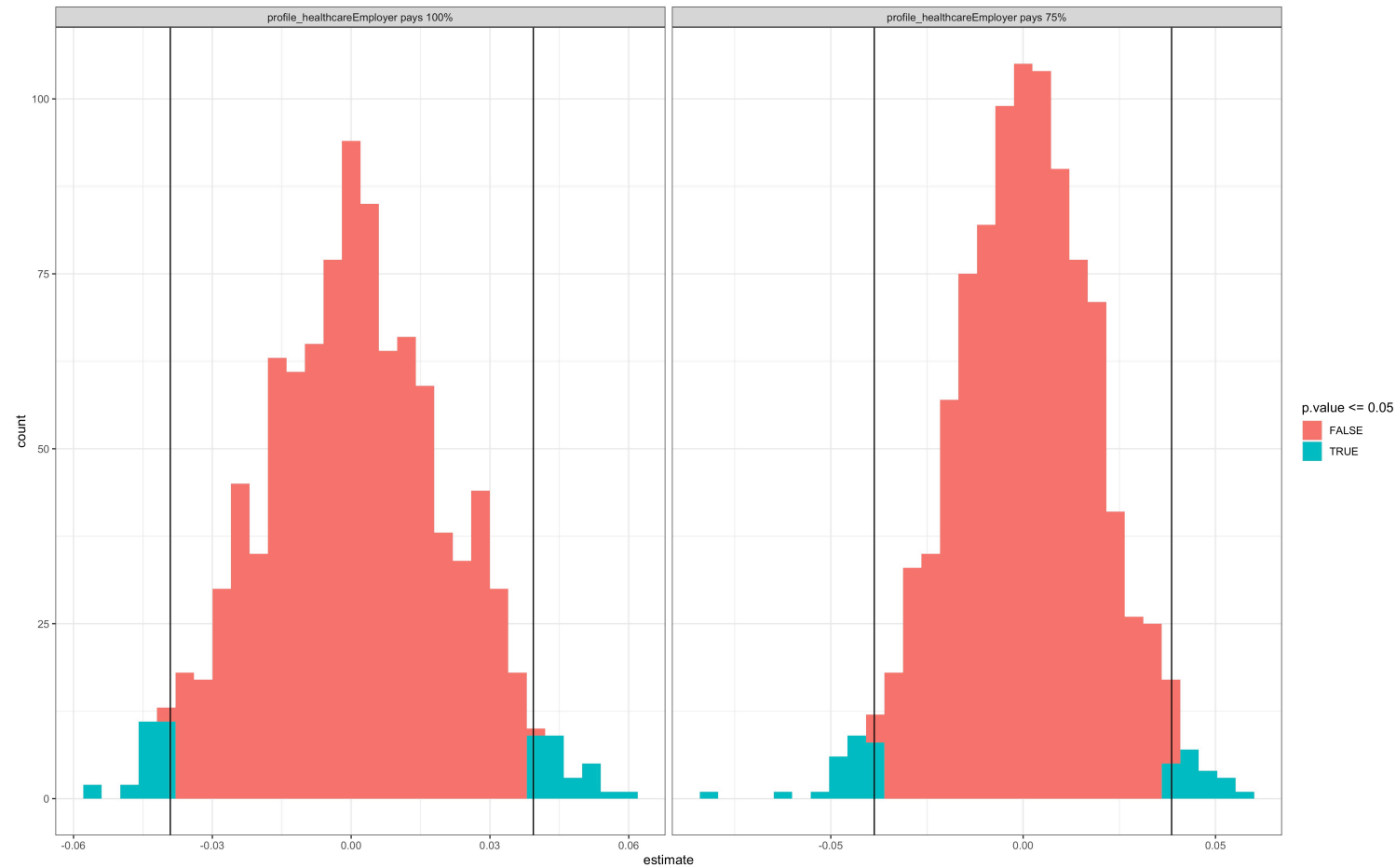

Figure 5: Power analysis of employer contributions to healthcare attribute levels. 


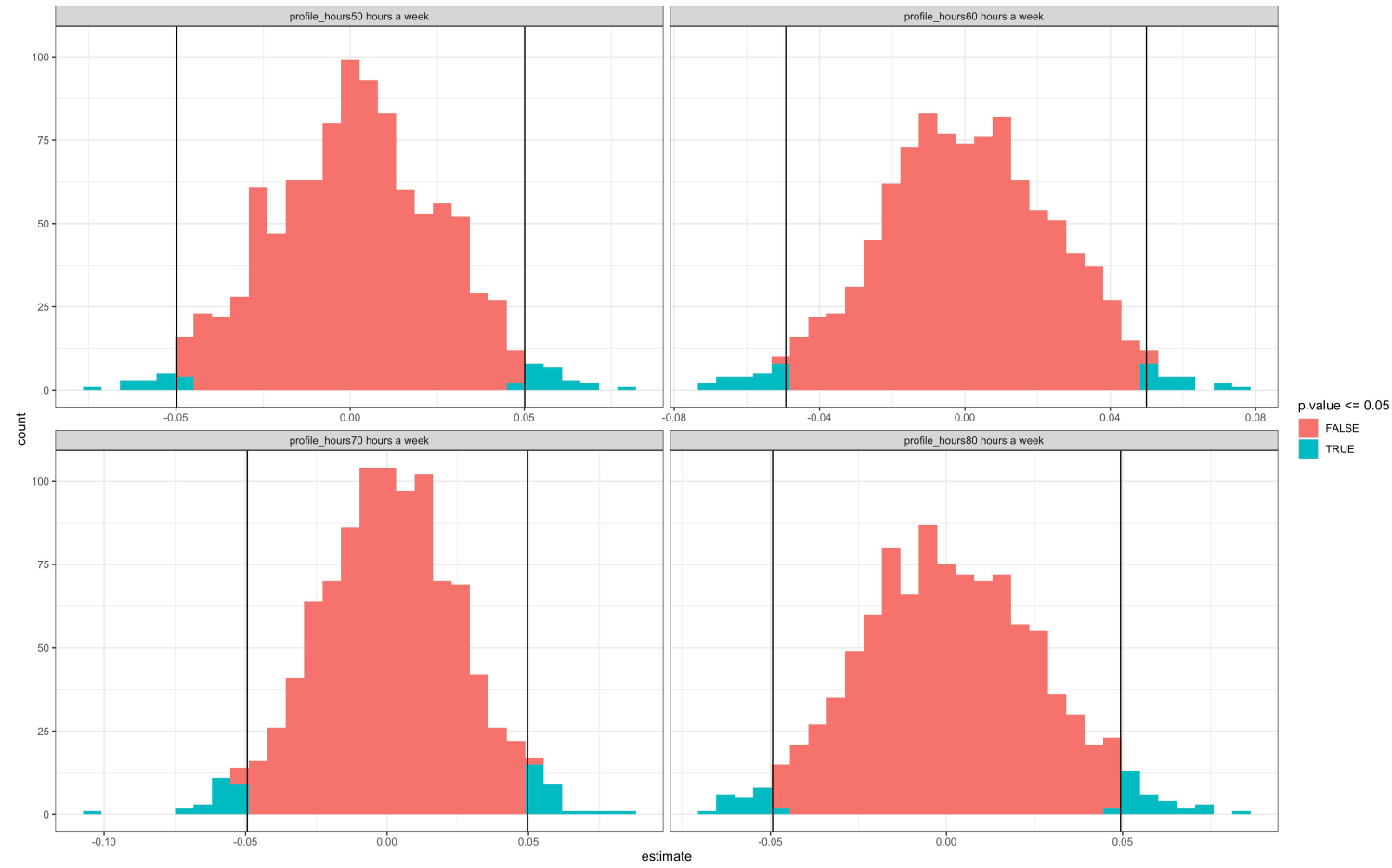

Figure 6: Power analysis of work hours attribute levels. 


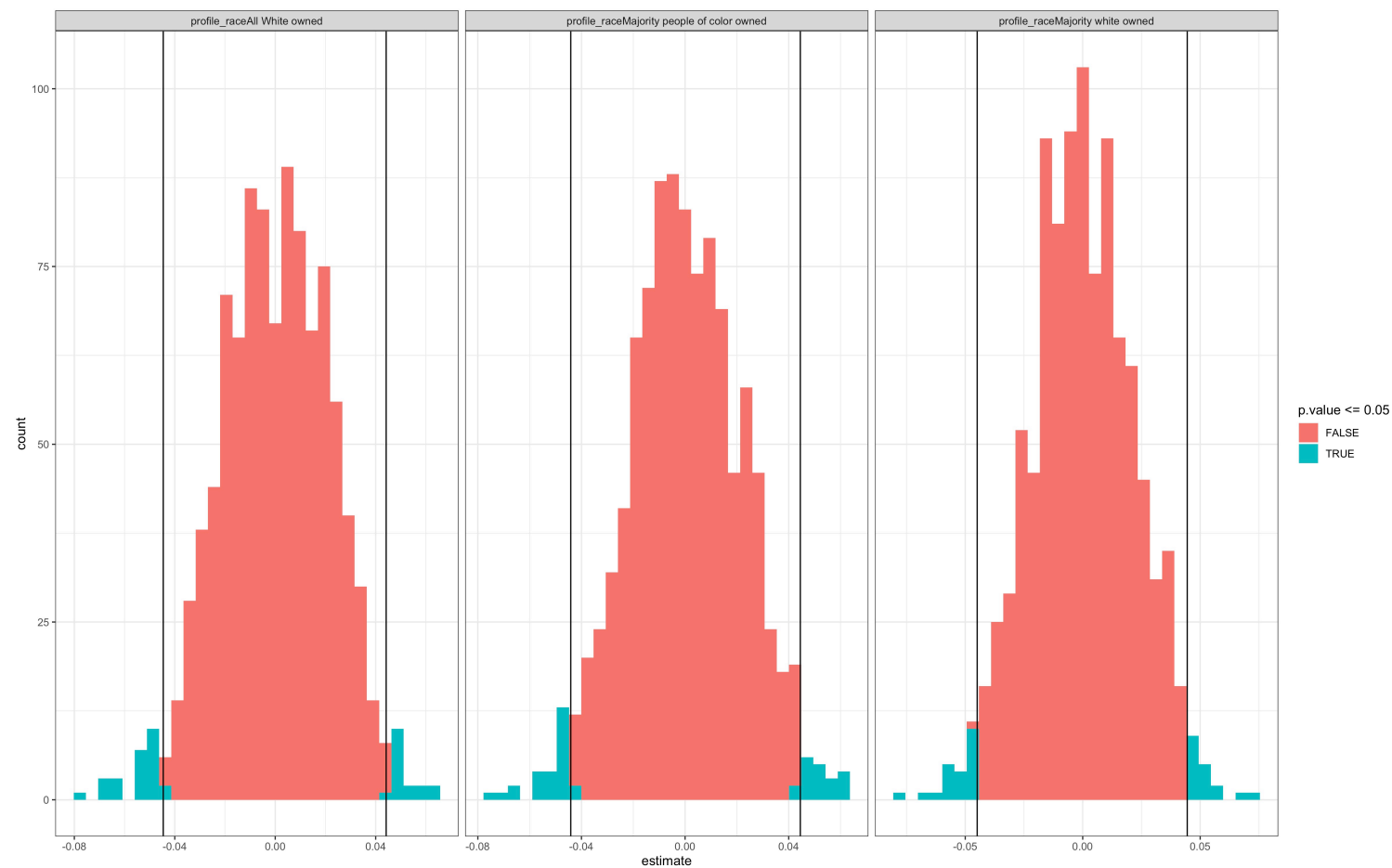

Figure 7: Power analysis of racial diversity of firm owners attribute levels. 


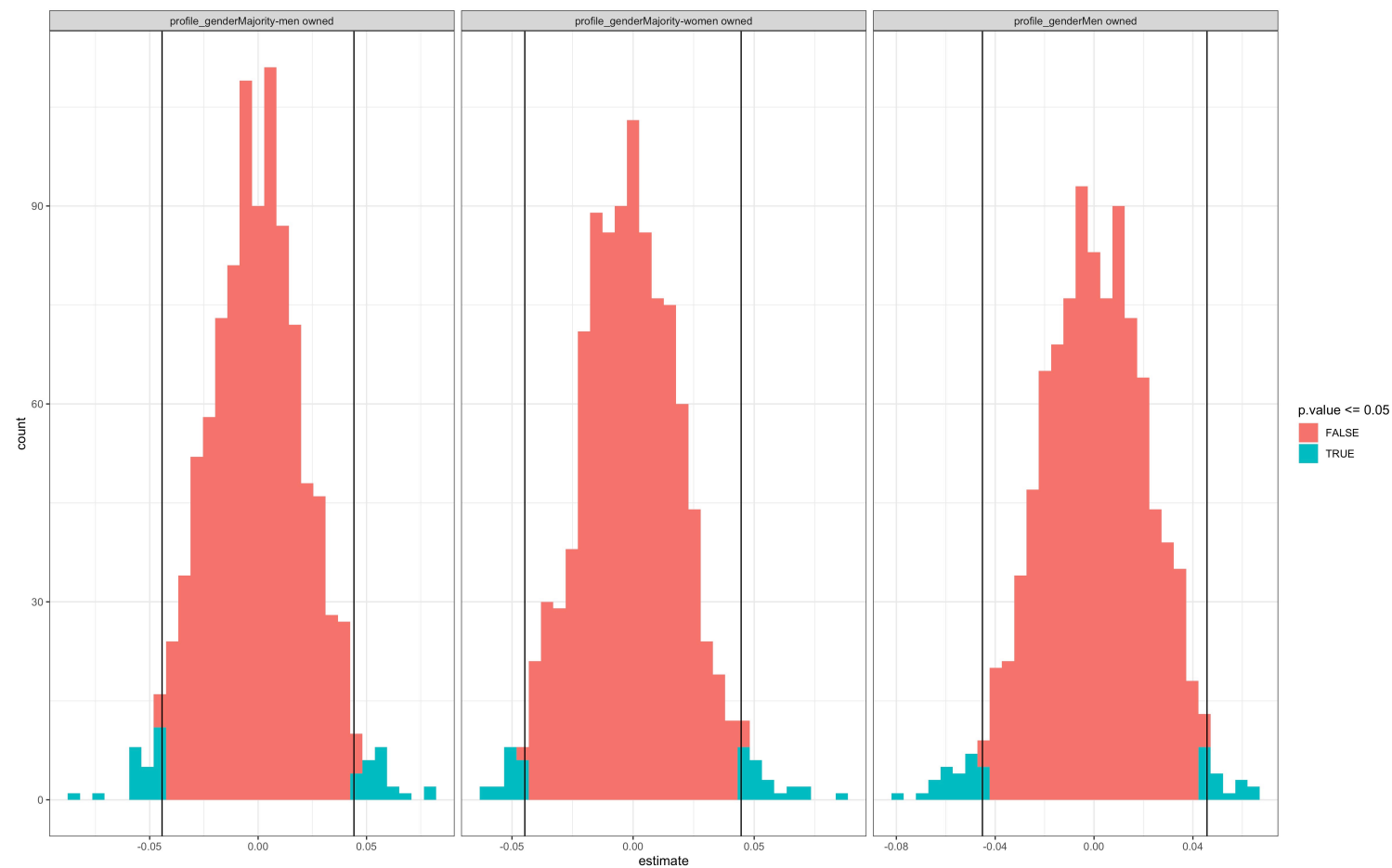

Figure 8: Power analysis of gender diversity of firm owners attribute levels. 


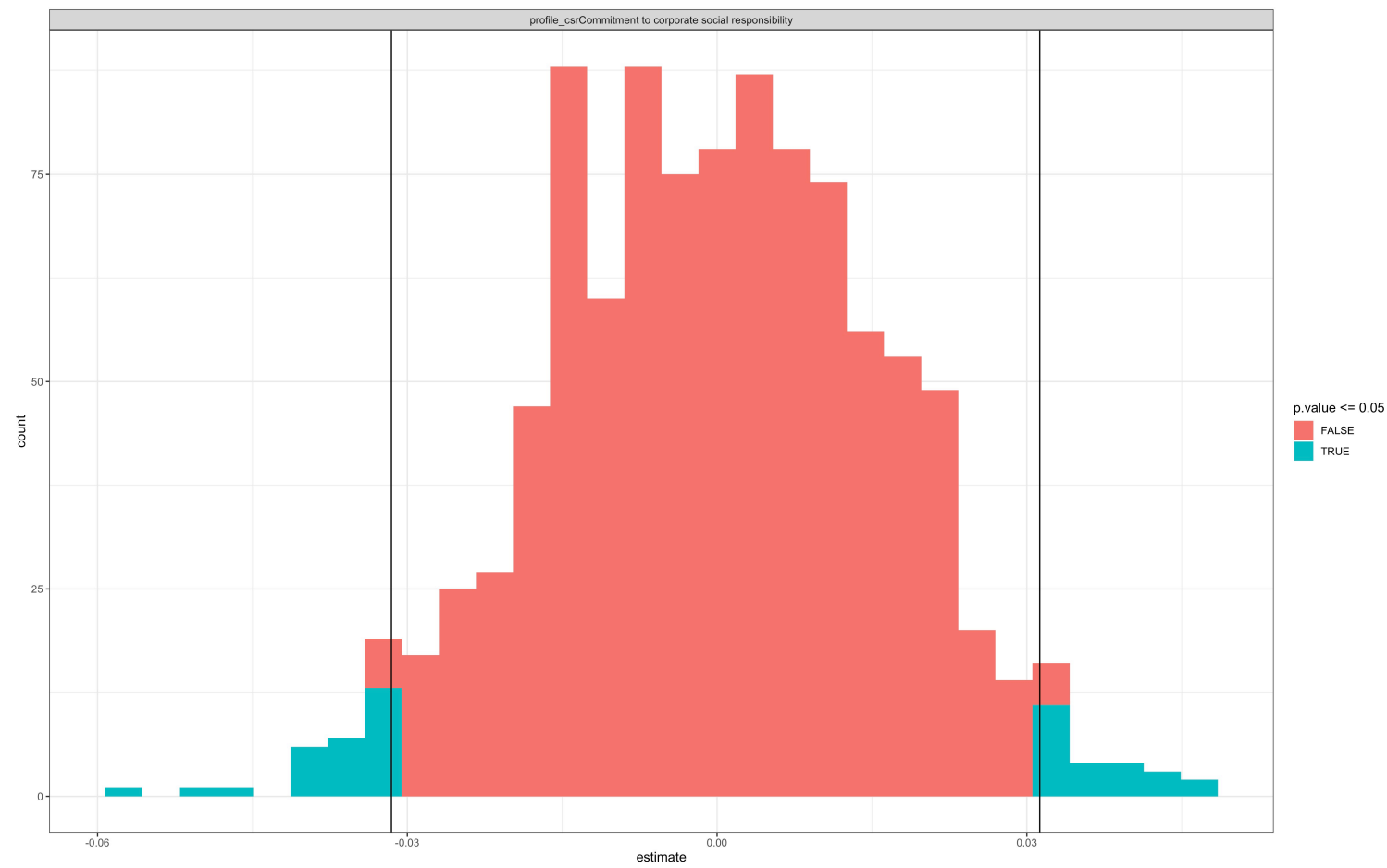

Figure 9: Power analysis of corporate social responsibility attribute levels. 


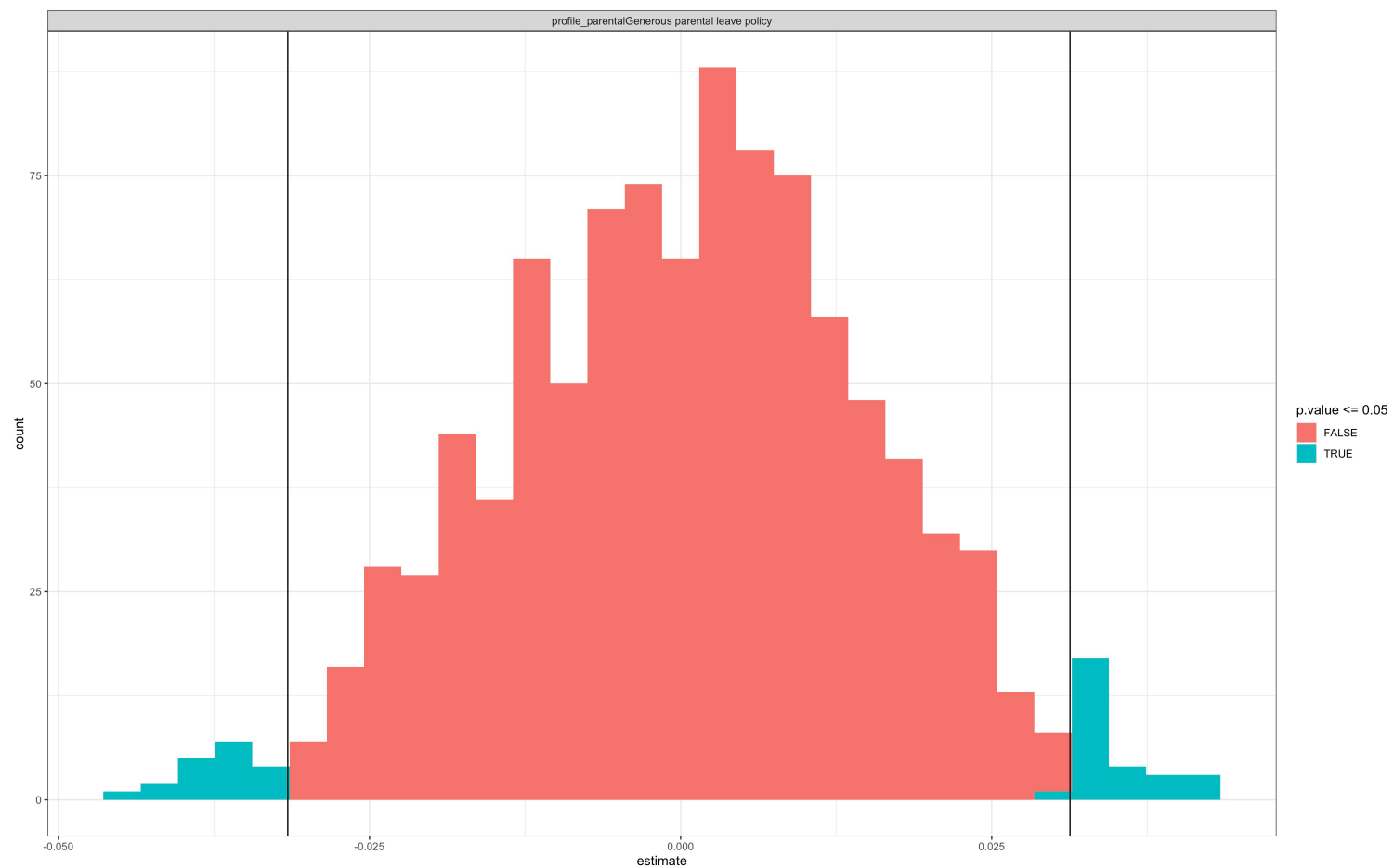

Figure 10: Power analysis of parental leave policy attribute levels. 


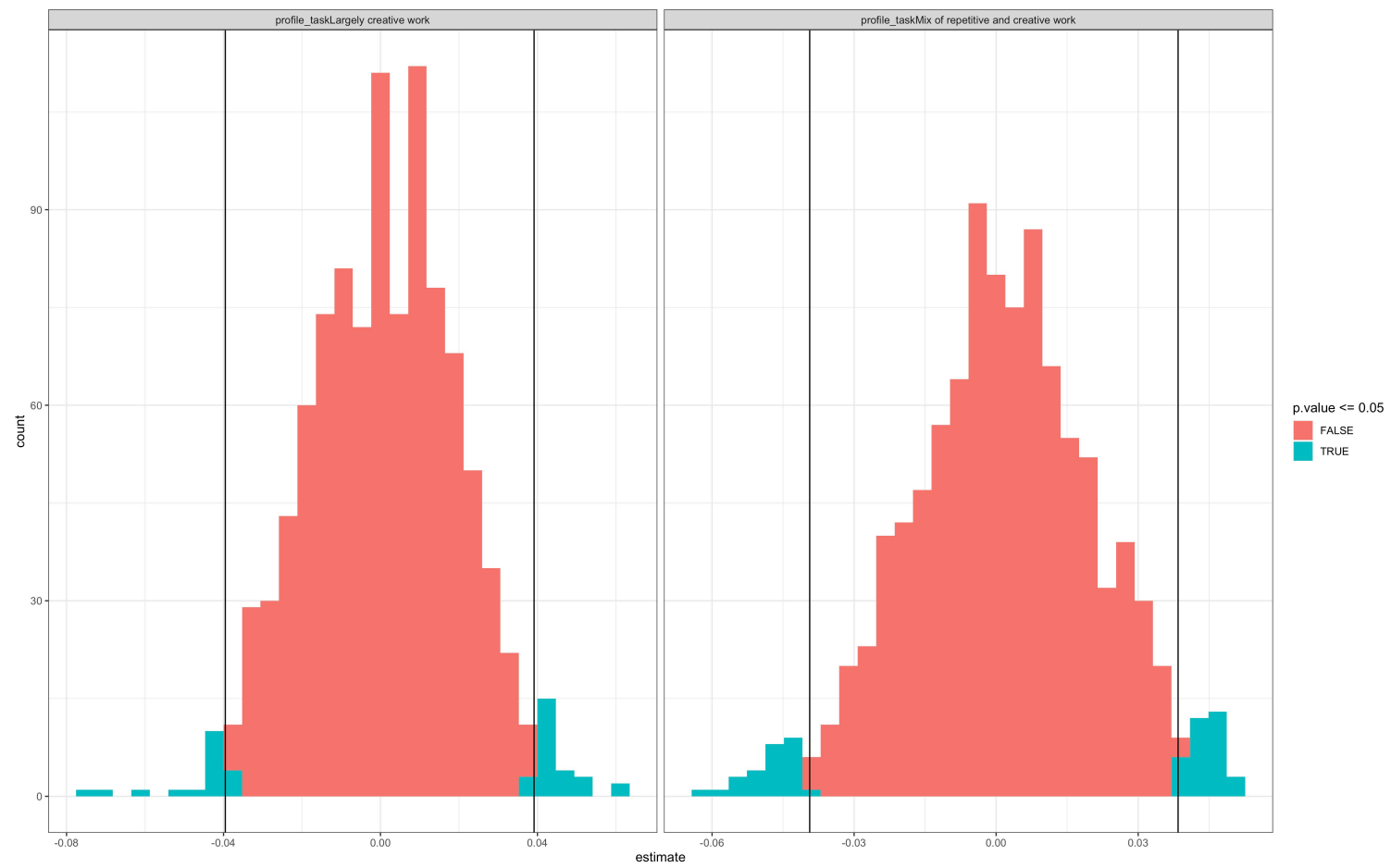

Figure 11: Power analysis of description of work tasks attribute levels. 


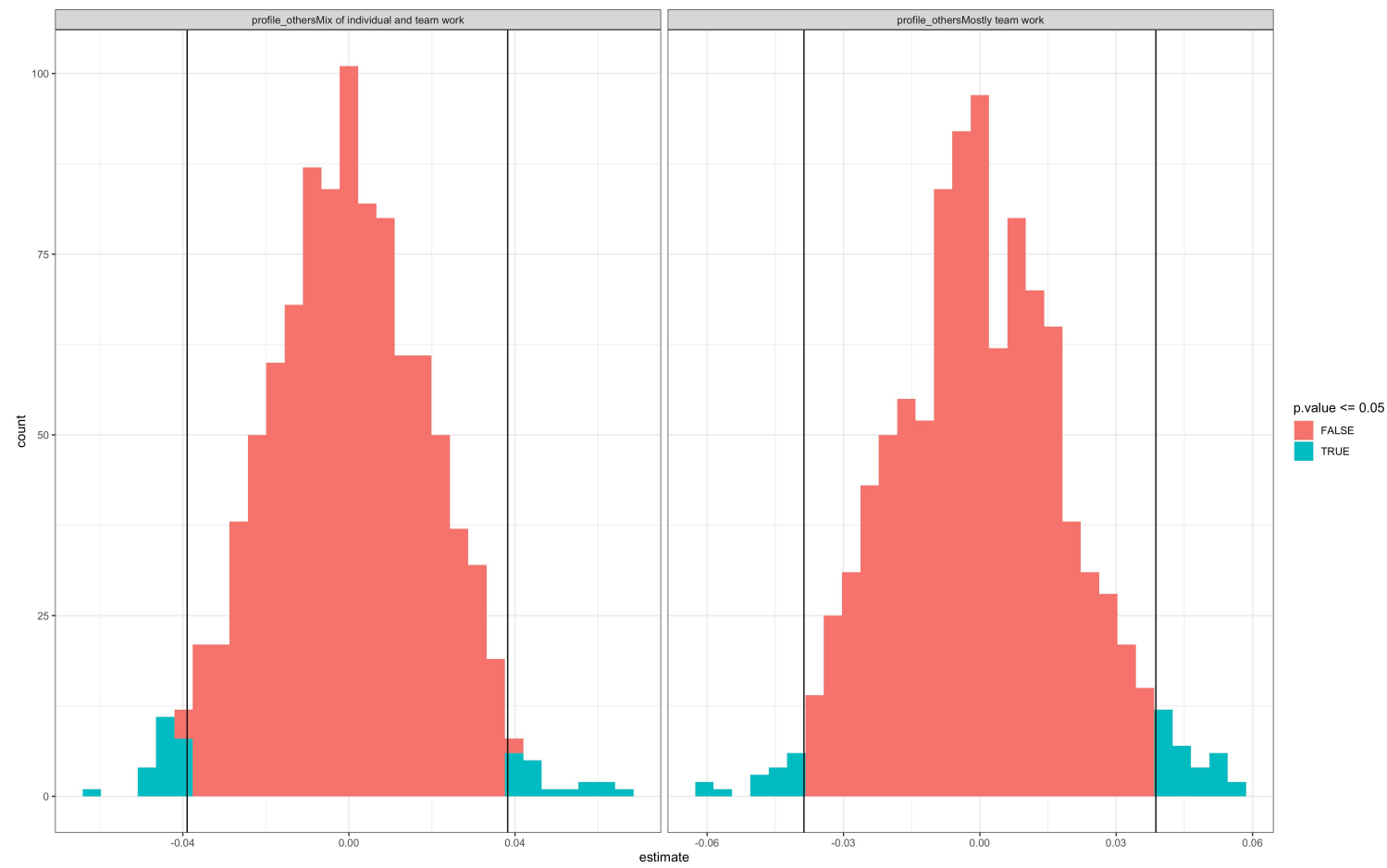

Figure 12: Power analysis of working with others attribute levels. 


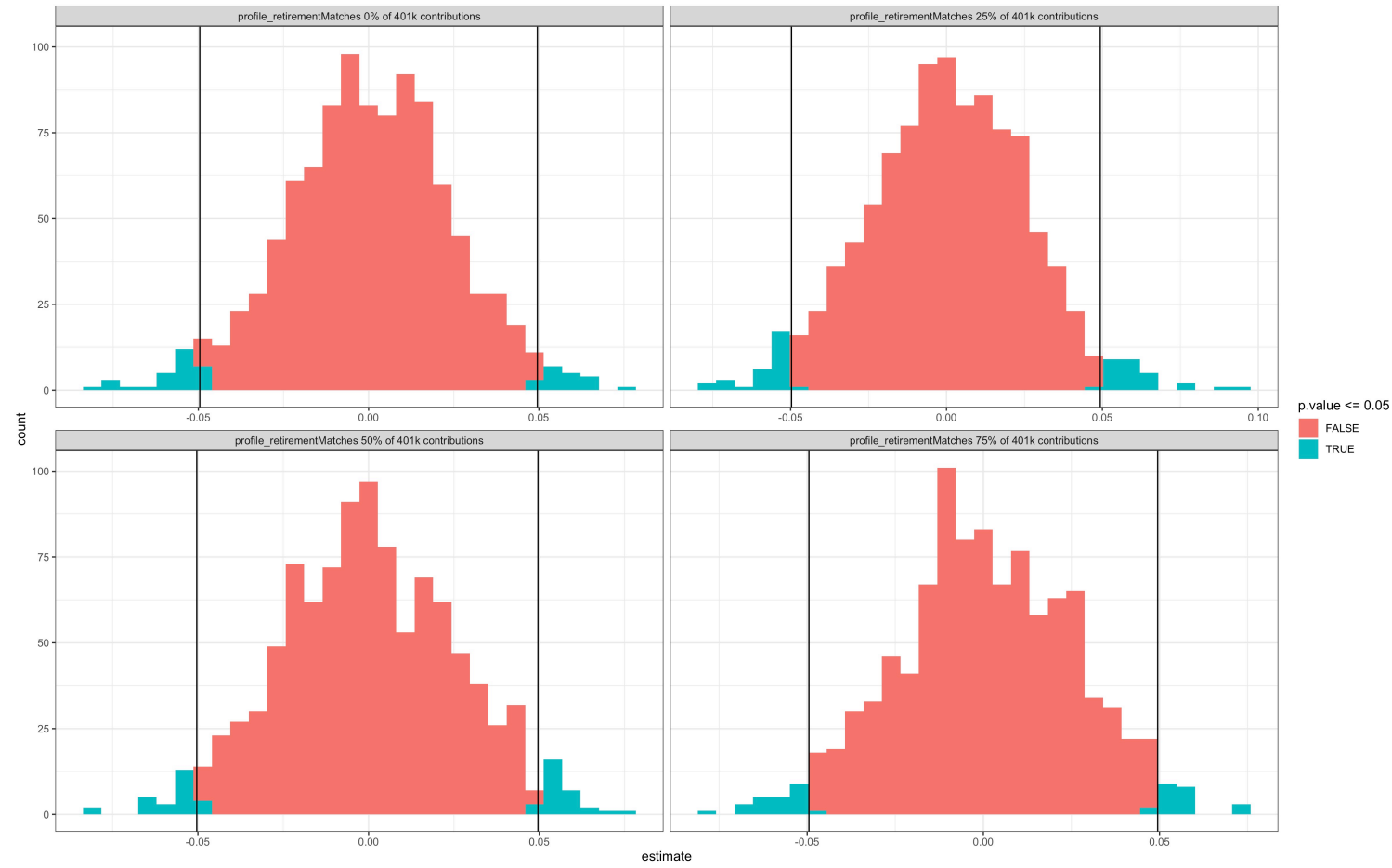

Figure 13: Power analysis of retirement policy attribute levels. 


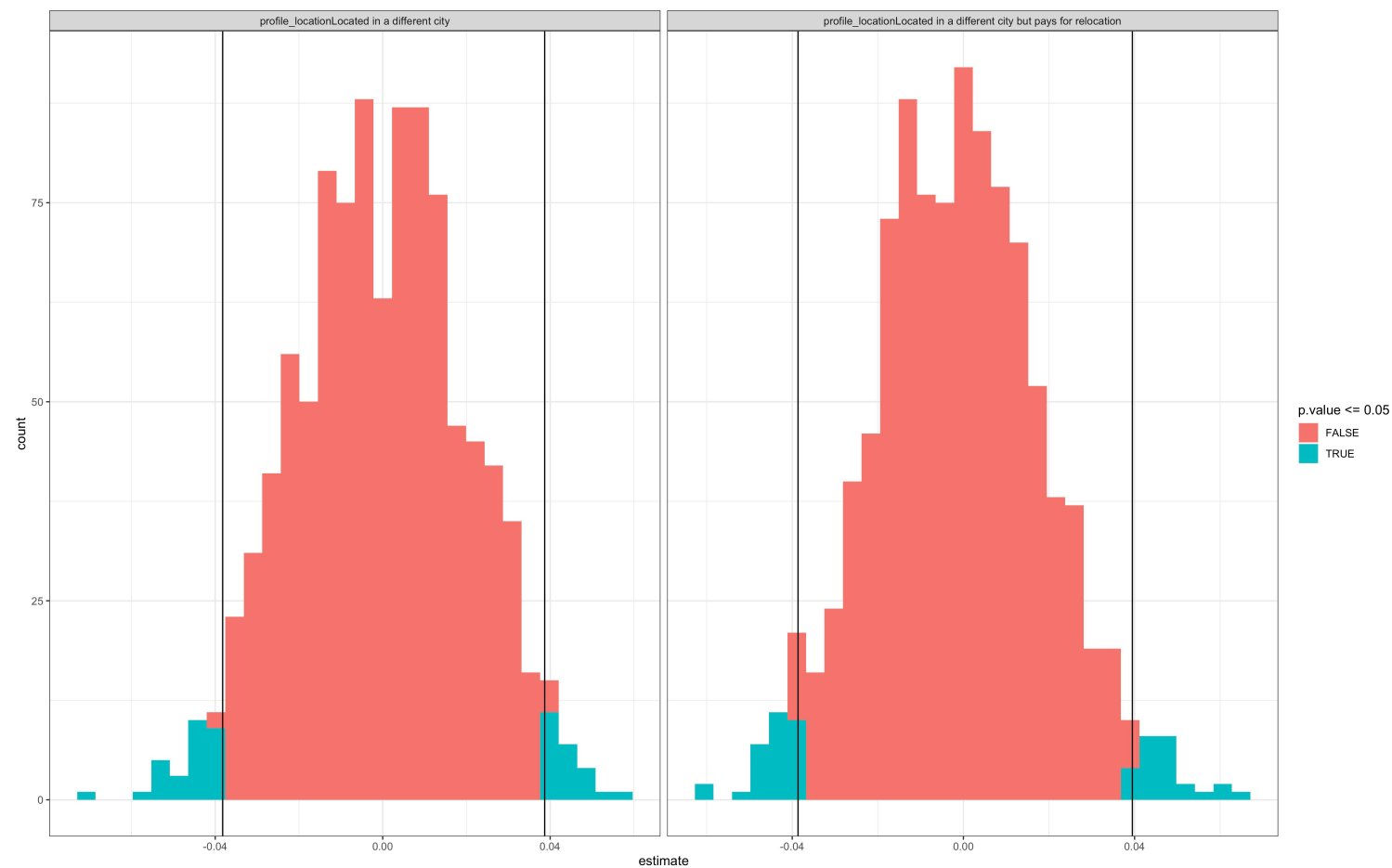

Figure 14: Power analysis of job relocation attribute levels. 


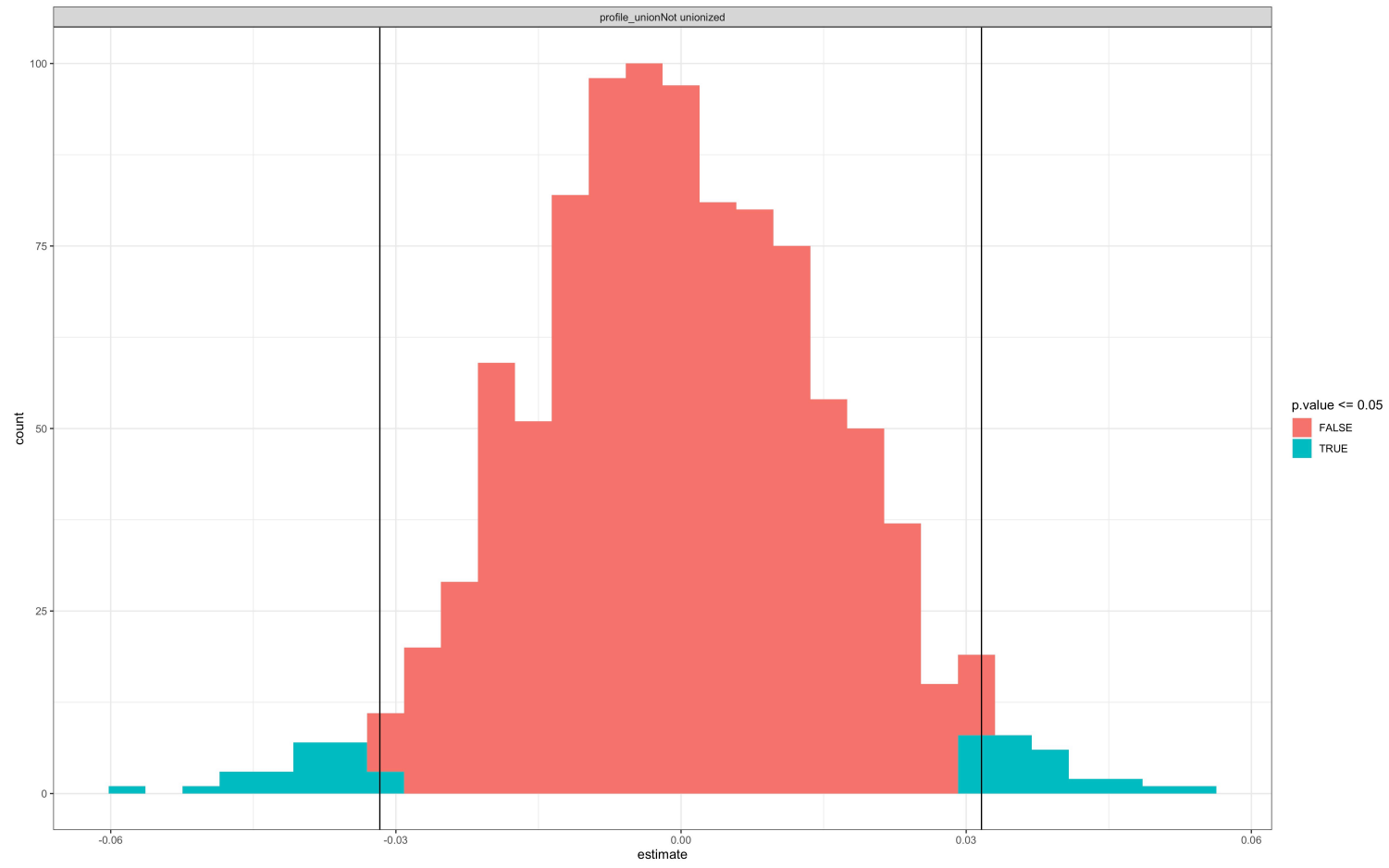

Figure 15: Power analysis of unionization attribute levels. 


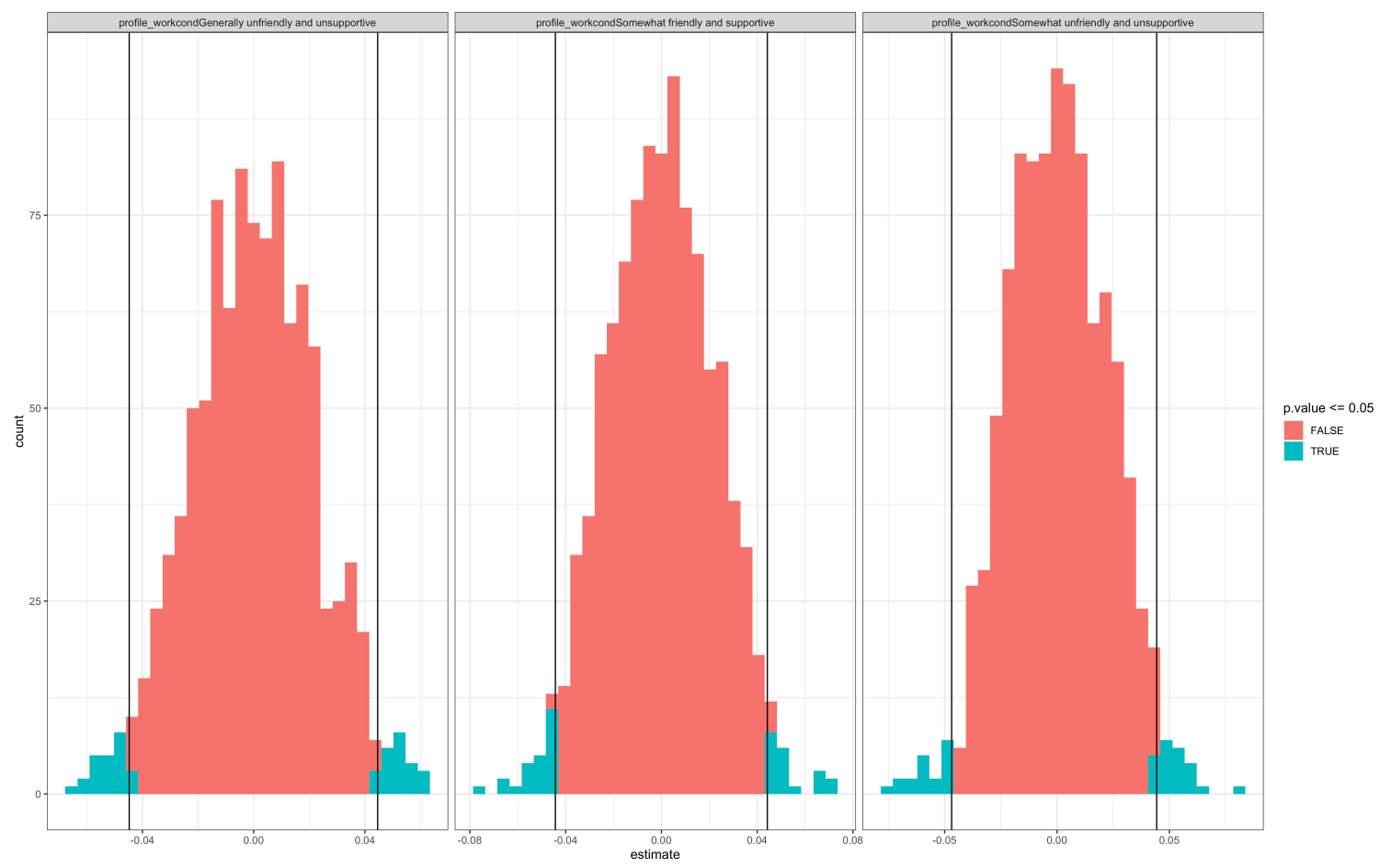

Figure 16: Power analysis of work conditions attribute levels. 


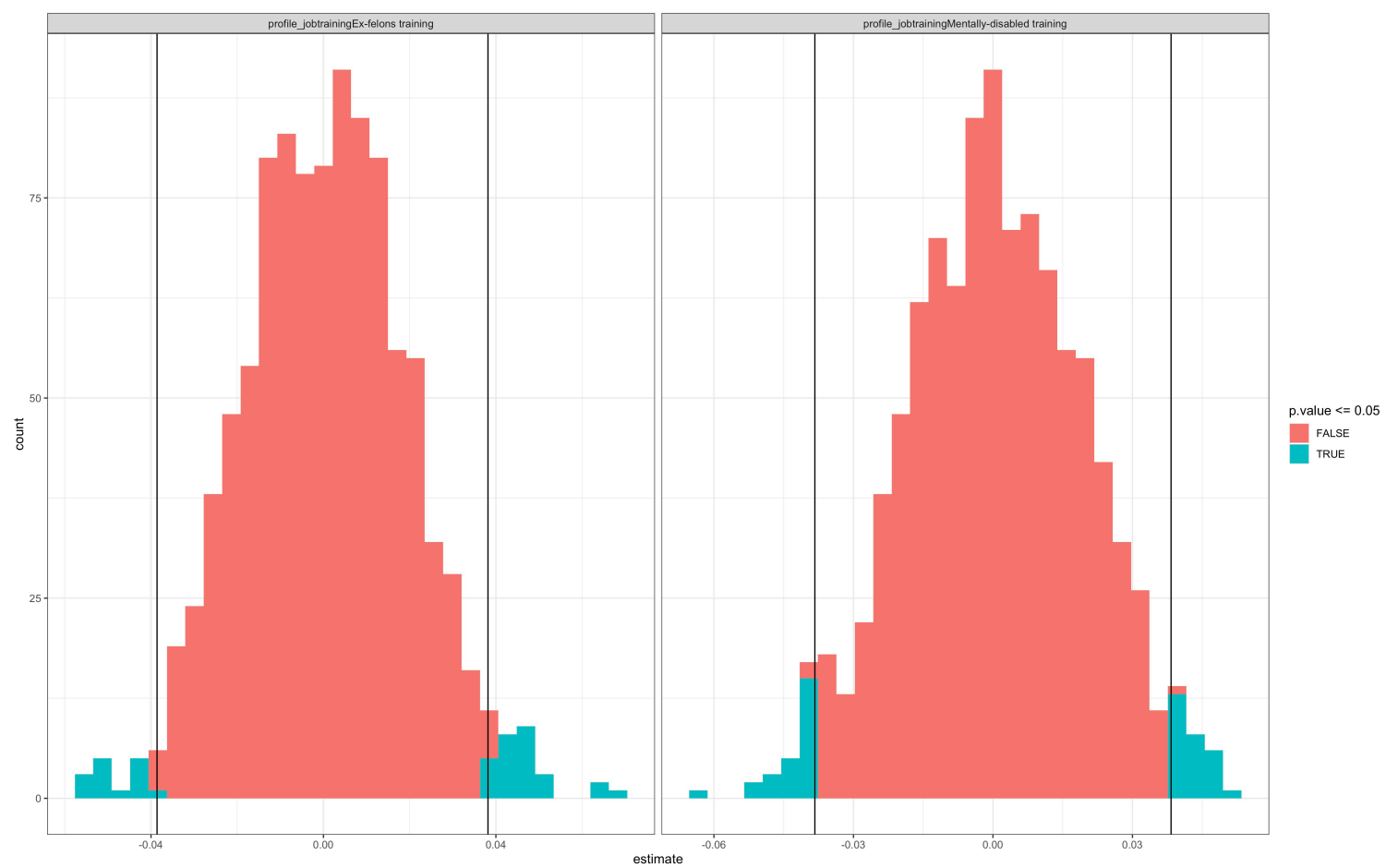

Figure 17: Power analysis of specialized job training attribute levels. 


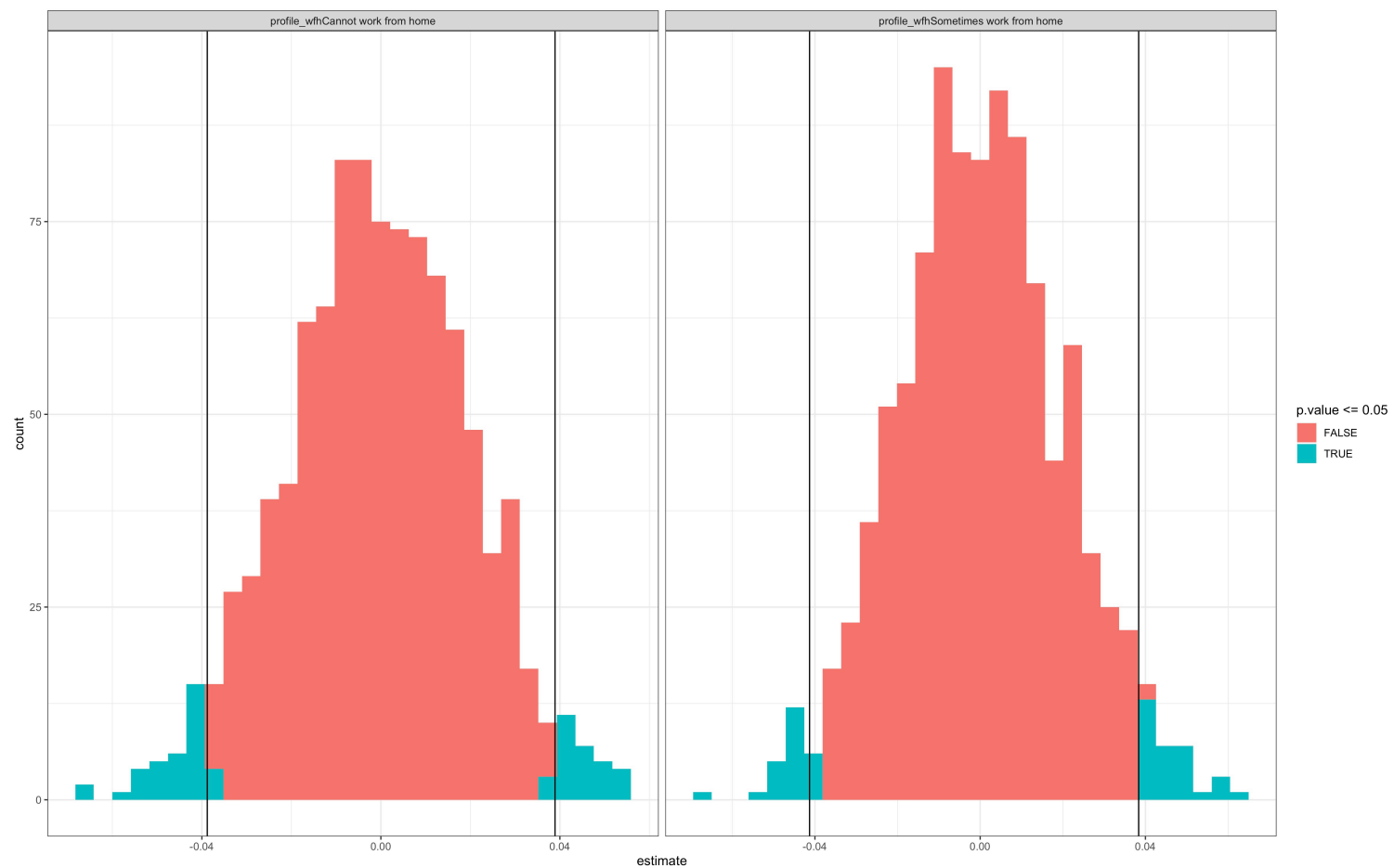

Figure 18: Power analysis of work from home policy attribute levels. 


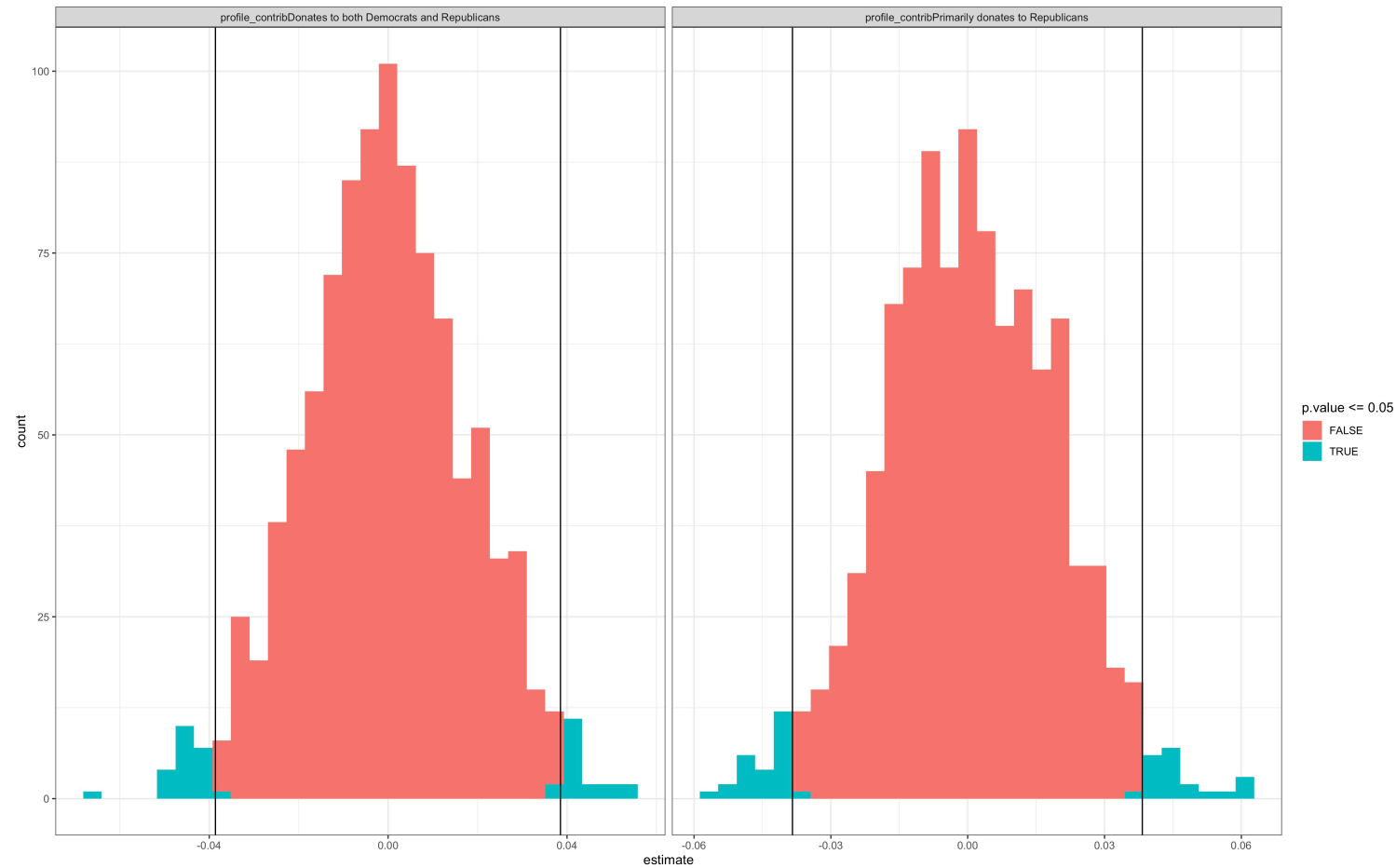

Figure 19: Power analysis of political contributions attribute levels. 

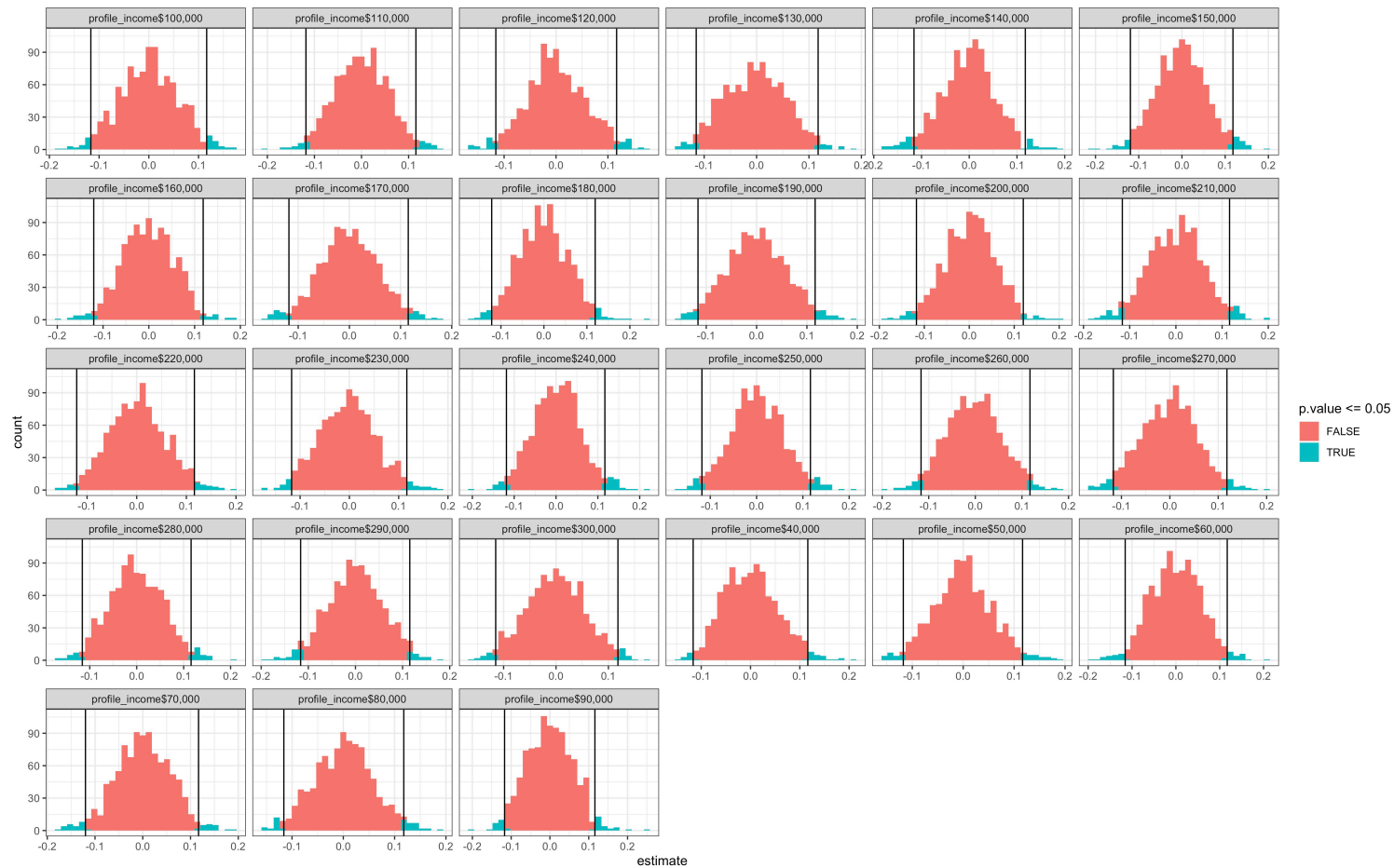

Figure 20: Power analysis of income offer attribute levels. 


\section{References}

Anderson, Elizabeth. 2017. Private Government: How Employers Rule Our Lives (and Why We Don't Talk about It). Princeton University Press.

Bansak, Kirk, et al. 2018. "The number of choice tasks and survey satisficing in conjoint experiments." Political Analysis 26 (1): 112-119.

Beglo, Miriam, and Luise Gorges. 2018. "On the Nature of Nuture: The Malleability of Gender Differences in Work Preferences." Journal of Economic Behavior and Organization 151:1941.

Coase, R.H. 1937. “The Nature of the Firm.” Economica 4 (16): 386-405.

Dahl, Robert A. 1986. A Preface to Economic Democracy. University of California Press.

Eriksson, Tor, and Nicolai Kristensen. 2014. "Wages or Fringes? Some Evidence on Trade-Offs and Sorting." Journal of Labor Economics 32 (4): 899-928.

Flory, Jeffrey A., Andreas Leibbrandt, and John A. List. 2015. "Do Competitive Workplaces Deter Female Workers? A Large-Scale Natural Field Experiment on Job-Entry Decisions." Review of Economic Studies 82 (1): 122-155.

Freeman, Richard B., and Joel Rogers. 2006. What Workers Want. Russell Sage Foundation.

Gourevitch, Alex. 2014. From Slavery to the Cooperative Commonwealth: Labor and Republican Liberty in the Nineteenth Century. Cambridge University Press.

Hainmueller, Jens, Dominik Hangartner, and Teppei Yamamoto. 2015. "Validating Vignette and Conjoint Survey Experiments against Real-World Behavior." Proceedings of the National Academy of Science 112 (8): 2395-2400.

Hainmueller, Jens, and Daniel J Hopkins. 2014. “The Hidden American Immigration Consensus: A Conjoint Analysis of Attitudes toward Immigrants." American Journal of Political Science 59 (3): 529-548. 
Hainmueller, Jens, Daniel J. Hopkins, and Teppei Yamamoto. 2014. "Causal Inference in Conjoint Analysis: Understanding Multidimensional Choices via Stated Preference Experiments." Political Analysis 22 (1): 1-30.

Hertel-Fernandez, Alexander, William Kimball, and Thomas Kochan. 2019. "How U.S. Workers Think About Workplace Democracy: The Structure of Individual Worker Preferences for Labor Representation.” Washington Center for Economic Growth Working Paper Series.

Hirschman, Albert O. 1972. Exit, Voice, and Loyalty: Responses to Decline in Firms, Organizations, and States. Harvard University Press.

Kochan, Thomas A., et al. 2019. "Worker Voice in America: Is There a Gap between What Workers Expect and What They Experience?" Industrial and Labor Relations Review 72 (1): 3-38.

Kostiuk, Peter F. 1990. “Compensating Differentials for Shift Work.” Journal of Political Economy 98 (5): 1054-1075.

Mas, Alexandre, and Amanda Pallais. 2017. "Valuing Alternative Work Arrangements." American Economic Review 107 (12): 3722-3759.

Strange, Austin M., et al. 2019. “Online Volunteer Laboratories for Human Subjects Research.” PLoS ONE 14 (8): 1-13.

Wiswall, Matthew, and Basit Zafar. 2018. "Preference for the Workplace, Investment in Human Capital, and Gender." Quarterly Journal of Economics 133 (1): 457-507.

Wright, Erik Olin. 1997. Class counts: Comparative studies in class analysis. Cambridge University Press. 